\title{
MORPHOLOGICAL, PHENOLOGICAL AND AGRONOMICAL CHARACTERISATION OF VARIABILITY AMONG COMMON BEAN (PHASEOLUS VULGARIS L.) LOCAL POPULATIONS FROM THE NATIONAL CENTRE FOR PLANT GENETIC RESOURCES: POLISH GENEBANK
}

\author{
Lech BOROS*, Anna WAWER, Krystyna BORUCKA \\ Plant Breeding and Acclimatization Institute - National Research Institute \\ Radzików , 05-870 Błonie, Poland \\ Received: July 10, 2014; Accepted: November 3, 2014
}

\begin{abstract}
The main purpose of this work was to analyse the morphological, phenological and agronomical variability among common bean local populations from The National Centre for Plant Genetic Resources, Polish Genebank, in order to know the relation among them, and to identify potentially useful accessions for future production and breeding. A considerable genotypic variation for number of seeds per plant, number of pods per plant and weight of seeds per plant were found. Studied bean accessions differed significantly in terms of thousand seeds weight (TSW) as well as severity of bacterial halo blight and anthracnose, the major bean diseases. The lowest genotypic diversity was found for the percentage of protein in the seeds, the length of the vegetation period and lodging. The cluster analysis allowed identification of five groups of bean accessions. Genotypes from the first cluster (POLPOD 98-77, KOS 002 and Raba cv.) and from the second cluster (WUKR 06-573a, KRA 4, WUKR 06-0534 together with Prosna cv.) are of the highest usefulness for breeding purposes. There was no grouping of local populations depending on region of origin.
\end{abstract}

Key words: dry bean, local populations, morphological characterisation, cluster analysis

\section{INTRODUCTION}

Among the grain legumes, common bean (Phaseolus vulgaris L.) is the only species with the relatively stable acreage in Poland. This is linked with tradition of cultivation and with availability of new improved cultivars, which affected stable acreage of dry bean cultivation (Szyrmer \& Boros 1997; Boros et al. 2001). Common bean is the third crop in the world in terms of the production of grain legume after soya bean (Glycine max (L.) Merr.) and groundnut (Arachis hypogaea L.). According to FAO data (FAOSTAT 2014), the annual worldwide production of bean in 2012 was 23.6 million tons from growing on the 53.7 million hectares. In Europe, dry bean was cultivated on 263 thousand hectares with the annual production of 486 thousand tones. Poland with the area of 13.5 thousand hectares and a production of 29.2 thousand tones takes top place in Europe in terms of dry beans cultivation.

The species Phaseolus vulgaris L. has two centres of origin, a Mesoamerican and an Andean (Singh et al. 1991). Much of the genetic variability of this species in the world has been maintained and conserved ex situ, outside the centers of origin, in gene banks. At present, there are at least 20 large professional collections of common bean in the world with the largest at the Center for Tropical Agriculture (CIAT; Cali Columbia) than Western Regional Plant Introduction Station, Pullman (Washington USA), Institute für Pflanzengenetik und 
Kulturpflanzenforschung (IPK; Gatersleben, Germany), and the N.I. Vavilov Research In-stitute of Plant Industry (VIR; Russia) (Lioli \& Piergiovanni 2013). The collection of bean (Phaseolus ssp.) maintained at the National Center for Plant Genetic Resources, Polish Genebank at Radzików had over 3000 accessions (personal information from M. Zaczyński). Among them are local populations collected during research expeditions carried out by Polish scientists to Slovak, Czech, Lithuania, Ukraine and Balkan regions. Part of the accessions also came from exchanging materials with other gene banks in the US, Hungary, Spain, Germany and France. The maintenance of this diversity in collections is fundamental to develop and support breeding programs. For a practical use and exploitation of the germplasm conserved in gene banks, its characterisation is essential. Several traits can be used to characterise genetic resources (Singh 2001). Our objectives were to assess the morphological, phenological and agronomical variation in common bean local populations from germplasm collection in order to improve collecting strategies, to know the relation among studied populations, and to identify potentially useful populations for future production and breeding.

\section{MATERIALS AND METHODS}

The twenty two common bean (Phaseolus vulgaris L.) local populations, from National Centre for Plant Genetic Resources, Polish Genebank were evaluated in field trial in 2010-2013. Among the populations studied 10 came from different areas of Poland, another 10 from Western Ukraine, one from the North Romania and one from Moldova. Additionally, two Polish cultivars, small seeded 'Raba' and medium-large seed 'Prosna' were included as a reference cultivars The experimental design was a randomised complete block with three replications. Each plot consisted of two rows $2 \mathrm{~m}$ long with row spacing of $30 \mathrm{~cm}$ and plant spacing of $10 \mathrm{~cm}$. Standard bean crop agricultural management was applied.

The bean accessions were evaluated according to IBPGR Phaseolus L. Descriptor (IBPGR 1982). The beginning of flowering (days from sowing to
$50 \%$ of plants on plots had at least one open flower), length of flowering (days from beginning of flowering until 50\% of plant finished flowering) vegetation period (days from sowing to $90 \%$ of plants with dry pods ready to harvest) were recorded on plot average basis. At the beginning of ripening, resistance to anthracnose [Colletotrichum lindemuthianum (Sacc. et Magn) Briosi] and halo blight [Pseudomonas syringae pv. phaseolicola (Burkh.) Young, Dye] with a scale of following degree of resistance: 1 - very low, over $75 \%$ of the infected plants; 3 -low, $51-75 \%$ of the infected plants; 5 - medium, $26-50 \%$ of the infected plants; 7 - high, up to $25 \%$ of the infected plants; 9 - very high, lack of the infected plants were performed.

Ten plants per plot were taken for the evaluation of plant height, height of first pod setting, number of pods per plant, seeds per pod, seeds per plant, seed yield per plant $(\mathrm{g})$, and 1000 seeds weight TSW (g). Additionally, colour of flowers (stand$\operatorname{ard}$ /wings), colour of matured pods, beak length and curvature, seed coat colour, pattern and seed shape were recorded.

Two-factor ANOVA analysis of variance, variance component analysis with REML method and Ward's clustering methods with squared Euclidean distance were performed with software Statgrafics Plus and SAS 9.3.

\section{RESULTS AND DISCUSSION}

Data related to various qualitative traits are presented in Table 1. All tested accessions showed bush growth type and were dry pules types. Ten local populations that were collected in Poland and four from Ukraine had white flowers, similarly to cvs. Prosna and Raba. The eight accessions of colour flowers showed also colour seed coat. Among them five showed mottled and one striped pattern on seed coat. The white seed coat colour of Polish local populations reflects earlier consumer preferences, which now are changing towards greater acceptance of colour bean seeds used for various dishes. Among tested accessions, the kidney and round seed shape were in equal proportion (36\% each), subsequently also in equal proportion were cuboid and oval seed shape (14\% each). Besides growth type 
remaining qualitative traits of local populations represent quite broad variations comparable to those in others studies (Hołubowicz et al. 2004; Bralewski et al. 2007; Horňáková et al. 2003; Stoilova et al. 2005; Casquero et al. 2006).

Analysis of variances of quantitative traits showed significance of bean genotypes and growing seasons as well as their interaction (Table 2). Variance components estimations showed that environmental factors (years) strongly influenced most of the evaluated traits of tested common bean accessions (Table 3). The highest shared genetic components in total variance was found for 1000 seeds weight and proteins content in seeds followed by seed and pod number per plant, symptoms of bacteriosis and anthracnose. The interaction effects of bean accessions with years of study were in the range from $7.9 \%$ for seeds per pod to $43.6 \%$ for length of flowering of total variance, which points to some differences in reaction of tested local populations to weather and soil conditions during growing seasons.

Mean, maximum and minimum values with coefficient of variation for fourteen qualitative characters of local populations are presented in Table 4. The lowest genotypic diversity was found for days to first flowering, flowering duration, the length of the vegetation period and lodging scores similarly to report by Hołubowicz et al. (2004), Casquero et al. (2006) and Stoilova et al. (2005, 2013). The protein content was $22 \%$ with minimum $21 \%$ and maximum $24.1 \%$. These results are consistent with obtained by Mavromatis et al. (2007) and Gouveia et al. (2014), but show a lower variation in bean seeds.

Table 1. Morphological characteristics of the local populations of dry bean

\begin{tabular}{|c|c|c|c|c|c|c|}
\hline No & Accession code/cultivar & $\begin{array}{l}\text { Country } \\
\text { of origin }\end{array}$ & $\begin{array}{l}\text { Flower } \\
\text { colour }\end{array}$ & Seed coat colour & Seed coat pattern & Seed shape \\
\hline 1 & WUKR 06-0137 & UA & White & Yellow & Absent & Round \\
\hline 2 & WUKR 06-0164B & UA & White & White & Absent & Oval \\
\hline 3 & WUKR 06-0201a & UA & Violet & Cream/violet & Mottled & Kidney \\
\hline 4 & WUKR 06-0201b & UA & Pink & Cream/red & Striped & Cuboid \\
\hline 5 & WUKR 06-0059 & UA & White & Yellow & Absent & Round \\
\hline 6 & WUKR 06-0573a & UA & Violet & Brown & Absent & Oval \\
\hline 7 & WUKR 06-0534 & UA & Violet & Pink/violet & Mottled & Kidney \\
\hline 8 & WUKR 06-0170 & UA & White & White/brown & Around hilum & Kidney \\
\hline 9 & WUKR 06-0498a & UA & Violet & Brown & Absent & Kidney \\
\hline 10 & WUKR 06-1198f & UA & Violet & Cream/brown & Mottled & Oval \\
\hline 11 & MDAZAP 98-381 & MD & Violet & White/grey & Mottled & Round \\
\hline 12 & ROMMAR 06-139 & RO & Violet & Violet/cream & Mottled & Cuboid \\
\hline 13 & POLPOD 98-77 & PL & White & White & Absent & Round \\
\hline 14 & POLBIA 98-37A & PL & White & Yellow & Absent & Round \\
\hline 15 & POLBIA 98-124 & PL & White & White & Absent & Round \\
\hline 16 & POLZIE 98-119 & PL & White & White/brown & Around hilum & Cuboid \\
\hline 17 & POLLUB 06-04A & PL & White & White & Absent & Round \\
\hline 18 & POLKLO 53 & PL & White & Dark yellow & Absent & Kidney \\
\hline 19 & BP 120 & PL & White & White & Absent & Round \\
\hline 20 & KOS 002 & PL & White & White & Absent & Kidney \\
\hline 21 & Е 4366 & PL & White & White & Absent & Kidney \\
\hline 22 & KRA 4 & PL & White & White & Absent & Kidney \\
\hline 23 & Prosna cv. & PL & White & White & Absent & Kidney \\
\hline 24 & Raba cv. & PL & White & White & Absent & Oval \\
\hline
\end{tabular}


Table 2. Mean squares of the analysis of variance of the agronomic traits of 24 dry bean accessions

\begin{tabular}{|c|c|c|c|c|}
\hline \multirow{2}{*}{ Traits } & \multicolumn{4}{|c|}{ Source } \\
\hline & Years & Accessions & $\mathrm{Y} \times \mathrm{A}$ & Residual \\
\hline$d f$ & 3 & 23 & 69 & 192 \\
\hline Length of vegetative growth (days) & $1270.21^{* * *}$ & $51.49^{* * * *}$ & $20.57^{* * * *}$ & 2.25 \\
\hline Length of flowering (days) & $2420.48^{* * *}$ & $172.33^{* * *}$ & $100.79^{* * *}$ & 3.78 \\
\hline Length of vegetation period (days) & $23526.9^{* * *}$ & $1076.2^{* * *}$ & $333.07^{* * *}$ & 14.14 \\
\hline Plant height $(\mathrm{cm})$ & $3018.7^{* * *}$ & $125.21^{* * *}$ & $29.21^{* * *}$ & 9.82 \\
\hline Height of lowest pod (cm) & $96.7^{* * *}$ & $4.62^{* * *}$ & $2.93^{* * *}$ & 1.19 \\
\hline Lodging* & $48.89^{* * * *}$ & $1.79^{* * *}$ & $0.83^{* * *}$ & 0.4 \\
\hline Symptoms of anthracnose $\mathrm{e}^{* *}$ & $82.61^{* * * *}$ & $14.41^{* * *}$ & $3.41^{* * *}$ & 0.94 \\
\hline Symptoms of halo blight** & $96.98^{* * *}$ & $13.53^{* * *}$ & $3.47^{* * *}$ & 0.70 \\
\hline Pods number per plant & $1283.27^{* * *}$ & $155.88^{* * *}$ & $28.10^{* * * *}$ & 6.32 \\
\hline Seeds number per plant & $12921.0^{* * * *}$ & $1996.57^{* * *}$ & $328.37^{* * *}$ & 54.65 \\
\hline Seeds number per pod & $1.64^{* * *}$ & $1.22^{* * *}$ & 0.34 & 0.24 \\
\hline Seeds weight per plant (g) & $1662.05^{* * *}$ & $119.52^{* * *}$ & $42.18^{* * *}$ & 9.66 \\
\hline 1000 seeds weight $(\mathrm{g})$ & $137175.0^{* * *}$ & $97585.5^{* * *}$ & $4908.59^{* * *}$ & 605.1 \\
\hline$\%$ of proteins in seeds & $10.24^{* * *}$ & $5.95^{* * *}$ & $0.69^{* * *}$ & 0.18 \\
\hline
\end{tabular}

* in 9-1 scale with 9 erect plants; ** in 9-1 scale with 9 no symptoms of disease

*** significance at $\mathrm{p}<0.01$

Table 3. Variance components estimation for the agronomic traits of 24 dry bean accessions (4-years average)

\begin{tabular}{lcccc}
\hline \multirow{2}{*}{\multicolumn{1}{c}{ Traits }} & \multicolumn{4}{c}{ REML estimates (\% of total variance) } \\
\cline { 2 - 5 } & Years & Accessions & Y $\times$ A & Residual \\
\hline Length of vegetative growth (days) & 61.4 & 9.1 & 21.6 & 7.9 \\
Length of flowering (days) & 43.4 & 8.0 & 43.6 & 5.0 \\
Length of vegetation period (days) & 63.9 & 12.3 & 21.0 & 2.8 \\
Plant height (cm) & 63.1 & 12.2 & 9.8 & 14.9 \\
Height of lowest pod (cm) & 40.5 & 4.4 & 18.0 & 37.1 \\
Lodging* & 50.3 & 6.1 & 9.4 & 34.2 \\
Symptoms of anthracnose** & 29.1 & 24.2 & 21.8 & 24.9 \\
Symptoms of halo blight** & 34.5 & 22.3 & 24.6 & 18.6 \\
Pods number per plant & 41.8 & 25.6 & 17.4 & 15.2 \\
Seeds number per plant & 38.0 & 30.2 & 19.8 & 12.0 \\
Seeds number per pod & 3.7 & 20.7 & 7.9 & 67.7 \\
Seeds weigh per plant (g) & 45.5 & 13.0 & 21.9 & 19.6 \\
1000 seeds weight (g) & 15.8 & 66.6 & 12.4 & 5.2 \\
\% of proteins in seeds & 14.3 & 47.4 & 18.5 & 19.8 \\
\hline
\end{tabular}

* in 9-1 scale with 9 erect plants; **in 9-1 scale with 9 no symptoms of disease 
Table 4. Mean, range and variation coefficient of the traits of 24 dry bean accessions (4-years average)

\begin{tabular}{lcccr}
\hline \multicolumn{1}{c}{ Traits } & Mean & Min & Max & CV \% \\
\hline Length of vegetative growth (days) & 46.8 & 43 & 52 & 4.3 \\
Length of flowering (days) & 31 & 25 & 36 & 12.0 \\
Length of vegetation period (days) & 121 & 101 & 132 & 7.6 \\
Plant height (cm) & 32 & 27 & 40 & 9.8 \\
Height of lowest pod (cm) & 8.5 & 7.0 & 9.7 & 7.2 \\
Lodging* & 7.5 & 7.0 & 8.2 & 5.1 \\
Symptoms of anthracnose** & 7.9 & 5 & 9.0 & 13.5 \\
Symptoms of halo blight** & 5.8 & 3.0 & 7.6 & 17.9 \\
Pods number per plant & 9.7 & 5.0 & 18.7 & 36.6 \\
Seeds number per plant & 30.6 & 13.0 & 59.0 & 41.2 \\
Seeds number per pod & 3.2 & 2.8 & 3.6 & 9.6 \\
Seeds weight per plant (g) & 10.2 & 4.2 & 17.2 & 30.2 \\
1000 seeds weight (g) & 365 & 192 & 529 & 24.1 \\
\% of proteins in seeds & 22.2 & 21.0 & 24.1 & 3.1 \\
\hline
\end{tabular}

* in 9-1 scale with 9 erect plants; **in 9-1 scale with 9 no symptoms of disease

Averages and ranges for the bean genotypes indicate considerable genotypic variation for the most important components of yield, including number of seeds per plant, number of pods per plant and weight of seeds per plant. High genotype variation for yield components was also observed by Bralewski et al. (2007), Horňáková et al. (2003), Stoilova et al. (2005, 2013), Casquero et al. (2006) in studies of common bean.

The studied accessions differed significantly in terms of 1000 seeds weight (TSW). According to Singh and Schwartz (2010), common bean seeds weight can vary from less than $150-900 \mathrm{~g}$ per 1000 seeds and are grouped into small-seed navy bean with TSW $<250 \mathrm{~g}$, medium up to $400 \mathrm{~g}$ and large-seed over $400 \mathrm{~g}$. In our study, 55\% of the evaluated accessions had medium size seeds and 30\% significantly larger seeds comparing to reference cv. Prosna. Previous studies of bean local populations from Polish collection showed the prevalence of medium and large seed accessions (Szyrmer et al. 1992; Nowosielski et al. 2002; Hołubowicz et al. 2004; Bralewski et al. 2007). Genotypes with small seeds had higher number of pods and seeds per plant, whereas large-seed types have fewer pods and seeds per plant. These data are consistent with those of Acquaah et al. (1991), who found that the pinto bean ideotype, which has larger seeds when compared with the navy bean ideotype, produces larger pods and larger seeds to compensate for the fewer pods per plant produced. Similarly, Nienhuis and Singh (1986) reported that selection for increased number of seeds per pod or pods per square meter resulted in reduced seed weight, and that the number of seeds per pod was often negatively correlated with seed size.

Disease evaluation confirmed prevalence of two main bean diseases - a bacterial origin hallo blight and anthracnose. The genotypic variation among accessions for incidence and severity of those diseases was observed. Average severity of anthracnose was lower than the halo blight disease. Two accessions were free of anthracnose.

In order to separate the groups of similar accessions within the set of local populations, multivariate analysis with the Ward's clustering method was carried out. The cluster analysis allowed to identify five homogenous groups (Table 5). The first group consisted of three accessions of small seeds, with the shortest period of vegetation, with no symptoms of anthracnose, low incidence and severity of bacterial disease, the highest number of pods and seeds per plant, with satisfactory seed yield per plant (POLPOD 98-77, KOS 002 and 'Raba'). The second group of four genotypes of high plant productivity beans brings together with low anthracnose and bacterial infection (WUKR 06573a, KRA 4, WUKR 06-0534 and 'Prosna').The 
third group of six genotypes having the longest vegetation period and medium-sized seeds. The fourth group consisted of accessions characterised by large seeds, mid-to-late vegetation period, susceptible to diseases and of high productivity. The largest group five ( 7 accessions) is characterised by early maturing and a high susceptibility to bacterial diseases and low plant productivity.

There was no grouping of accessions depending on region of origin. An exception was the first group, comprising Polish originated, small seed genotypes and Raba cv. (Fig. 1). The remaining ac- cessions of Polish and Ukrainian origin were scattered into four groups. These results are consistent with those obtained by Madakbas and Ergin (2011), who tested landraces collected from various region of Turkey. In their studies, landraces gathered from the same regions also were not grouped together in the cluster analysis.

Genotypes of the first cluster (POLPOD 98-77, KOS 002 and cv. Raba) and of the second cluster (WUKR 06-573a, KRA 4, WUKR 06-0534 and cv. Prosna) are of the highest usefulness for breeding purposes.

Table 5. The characteristics of separated clusters for tested dry bean accessions

\begin{tabular}{|c|c|c|c|c|c|}
\hline \multirow{2}{*}{ Traits } & \multicolumn{5}{|c|}{ Means for clusters of accessions } \\
\hline & 1 & 2 & 3 & 4 & 5 \\
\hline Length of vegetative growth (days) & 44 & 48 & 47 & 48 & 46 \\
\hline Length of flowering (days) & 30 & 34 & 33 & 33 & 27 \\
\hline Length of vegetation period (days) & 110 & 126 & 130 & 121 & 115 \\
\hline Plant height $(\mathrm{cm})$ & 30 & 35 & 30 & 35 & 31 \\
\hline Height of lowest pod (cm) & 8 & 9 & 8 & 9 & 8 \\
\hline Lodging* & 8 & 7 & 8 & 7 & 7 \\
\hline Symptoms of anthracnose $* *$ & 9 & 8 & 8 & 6 & 8 \\
\hline Symptoms of halo blight** & 7 & 7 & 6 & 5 & 5 \\
\hline Pods number per plant & 16 & 12 & 8 & 9 & 6 \\
\hline Seeds number per plant & 52 & 44 & 26 & 27 & 20 \\
\hline Seeds number per pod & 3.2 & 4 & 3.1 & 3 & 3.1 \\
\hline Seeds weight per plant (g) & 11 & 14 & 9 & 13 & 7 \\
\hline 1000 seeds weight $(\mathrm{g})$ & 216 & 328 & 369 & 477 & 385 \\
\hline$\%$ of all accessions & 12 & 17 & 25 & 17 & 29 \\
\hline
\end{tabular}

* in 9-1 scale with 9 erect plant; **in 9-1 scale with 9 no symptoms of disease

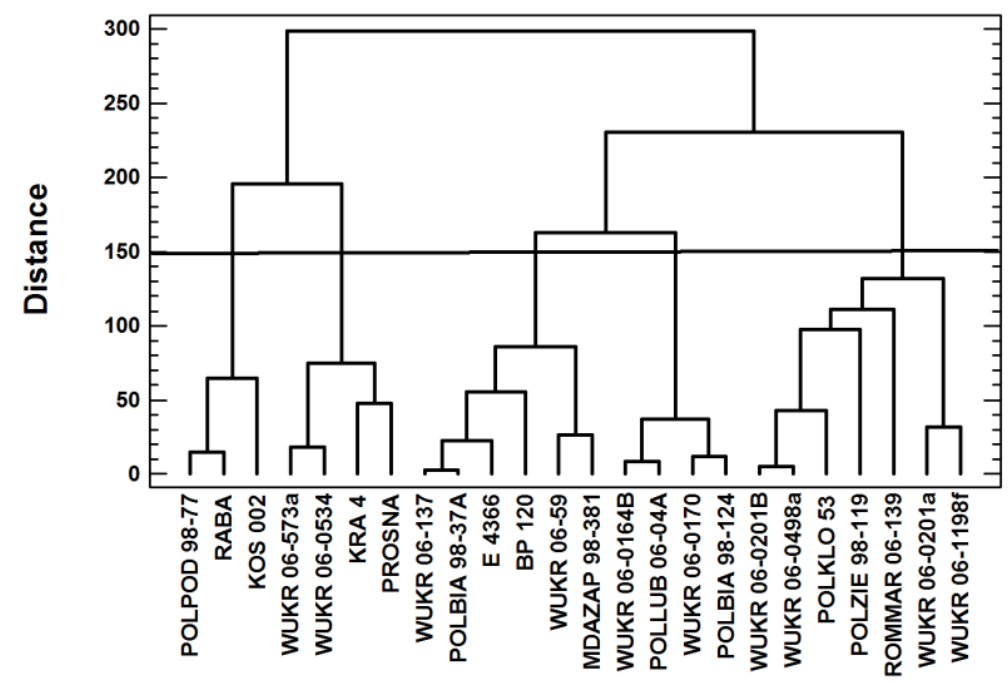

Fig. 1. Classification of dry bean accession into clusters with Ward's method 


\section{CONCLUSION}

The four-year long observations made possible to describe morphological traits, phenological stages, yielding structure, resistance to anthracnose and halo blight of 22 local populations of the common bean. A considerable genotypic variation for qualitative and quantitative characters among them for number of seeds per plant, number of pods per plant and weight of seeds per plant were stated. Studied bean local populations differed significantly in terms of TSW and severity of bacteriosis and anthracnose, the major bean diseases. The lowest genotypic diversity was found for the content of protein in the seeds, the length of the vegetation period and lodging. Applied cluster analysis allowed to identify five groups of bean local populations. The carried out research made possible indication of bean accessions, which could be a source of valuable characters in breeding new cultivars.

\section{Acknowledgements}

The authors are grateful to Dr. Teresa Kotlińska for collecting and providing bean germplasm.

\section{REFERENCES}

Acquaah G., Adams M.W., Kelly J.D. 1991. Identification of effective indicators of erect plant architecture in dry bean. Crop. Science 31: 261-264. DOI: 10.2135/cropsci1991.0011183X003100020004x.

Boros L., Waszkiewicz-Robak B., Szyrmer J., Wawer A. 2001. Agronomic performance and technological value of dry bean genotypes (Phaseolus vulgaris L.). Veget. Crops Res. Bull. 54(1): 33-41.

Bralewski T.W., Fiebig M., Kotlińska T. 2007. Characteristic of selected local cultivars of beans from Poland, Slovak Republic and Ukraine. Zesz. Problem. Post. Nauk. Rol. 517: 179-186. [in Polish with English abstract]

Casquero P.A., Lema M., Santalla M., De Ron A.M. 2006. Performance of common bean (Phaseolus vulgaris L.) landraces from Spain in the Atlantic and Mediterranean environments. Genetic Resources and Crop Evolution 53: 1021-1032. DOI: 10.1007/s10722-004-7794-1.

FAOSTAT 2014. http://faostat.fao.org

Gouveia C., Freitas G., Brito J., Slaski J., Carvalho M. 2014. Nutritional and mineral variability in $52 \mathrm{ac}-$ cessions of common bean varieties (Phaseolus vulgaris L.) from Madeira island. Agricultural Sciences 5: 317-329. DOI: 10.4236/as.2014.54034.

Hołubowicz R., Bralewski T., Fiebig M., Bocian S. 2004. Variabilty of selected characters of 18 local populations of bean (Phaseolus ssp.). EJPAU 7(1), \#08. http://www.ejpau.media.pl/volume7/issue1/horticulture/art-08.html

Horňáková O., Závodná M., Žáková M., Kraic J., Debre F. 2003. Diversity of common bean landraces collected in the Western and Eastern Carpatien. Czech J. Genet. Plant Breed. 39: 73-83.

International Board for Plant Genetic Resources (IBPGR) 1982. Descriptors for Phaseolus vulgaris. IBPGR Secretariat, Rome, Italy.

Lioi L., Piergiovanni A.R. 2013. European common bean. In: Singh M., Upadhyaya H.D., Bisht I.S. (Eds.), Genetic and Genomic Resources of Grain Legume Improvement pp. 11-40, Elsevier. DOI: 10.1016/B978-0-12-397935-3.00002-5.

Madakbaş S.Y., Ergin N. 2011. Morphological and phenological characterization of Turkish bean (Phaseolus vulgaris L.) genotypes and their present variation states. African Journal of Agricultural Research 6(28): 6155-6166. DOI: 10.5897/AJAR11.1361.

Mavromatis A.G., Arvanitoyannis I.S., Chatzitheodorou V.A., Khahe M., Korkovelos A.E., Goulas C.K. 2007. Landraces versus commercial common bean cultivars under organic growing conditions: a comparative study based on agronomic performance and physicochemical traits. Eur. J. Hortic. Sci. 72(5): 214-219.

Nienhuis J., Singh S.P. 1986. Combining ability analyses and relationships among yield, yield components, and architectural traits in dry bean. Crop Science 26: 21-27. DOI: 10.2135/cropsci1986.0011183X002600010005x.

Nowosielski J., Podyma W., Nowosielska D. 2002. Molecular research on genetic diversity of Polish varieties and landraces of Phaseolus coccineus and Phaseolus vulgaris L. using RAPD and AFLP methods. Cellular and Molecular Biology Letters 7(2B): 753-762.

Singh S.P., Gepts P., Debouck D.G. 1991. Races of common bean (Phaseolus vulgaris, Fabaceae). Econ. Bot. 45: 379-396. DOI: 10.1007/BF02887079.

Singh S.P. 2001. Broadening the genetic base of common bean cultivars: a review. Crop Science 41: 16591675. DOI: 10.2135/cropsci2001.1659. 
Singh S.P., Schwartz H.F. 2010. Breeding common bean for resistance to diseases: a review. Crop Science 50: 2199-2223. DOI: 10.2135/cropsci2009.03.0163.

Stoilova T., Pereira G., Tavers-de-Sousa M.M., Carnide V. 2005. Diversity in common bean landraces (Phaseolus vulgaris L.) from Bulgaria and Portugal. Journal of Central European Agriculture 6(4): 443-448.
Stoilova T., Pereira G., Tavers-de-Sousa M.M. 2013. Morphological characterization of a small common bean (Phaseolus vulgaris L.) collection under different environments. Journal of Central European Agriculture 14(3): 854-864. DOI: 10.5513/JCEAO01/14.3.1277.

Szyrmer J., Dembińska J., Wawer A. 1992. Vegetation course and variability of useful traits of cultivars and forms of Phaseolus vulgaris L. Biul. IHAR 180: 229-239. [in Polish with English abstract] 